\title{
Development of a Multi-professional and multi-agency Model, PLUSS (mental health, learning, development, collaboration around pre-school children), to Facilitate Early Detection and Support of Pre-School Children with Neurodevelopmental Difficulties in the Swedish Child Health Care - A Description of the Model and Initial Results
}

Berit M. Gustafsson ( $\square$ berit.m.gustafsson@liu.se)

Högland Hospital, Region Jönköping County

\section{Samina Steinwall}

Region Jönköping County

Laura Korhonen

Linköping University

\section{Research Article}

Keywords: preschool child, neurodevelopment, child health care, service development, intervention, multi-agency, multi-professional, preschool

Posted Date: September 13th, 2021

DOl: https://doi.org/10.21203/rs.3.rs-864070/v1

License: (c) This work is licensed under a Creative Commons Attribution 4.0 International License. Read Full License 


\section{Abstract}

Background: Neurodevelopmental difficulties are frequent in preschoolers and constitute a risk for later negative consequences. This article describes the development of a multi-professional and multi-agency model, PLUSS, to facilitate care and interventions for preschoolers with neurodevelopmental difficulties.

Methods: The PLUSS-model was developed for children aged 1.5-5 years with a need for a further assessment of neurodevelopmental symptoms. The model is evaluated using a quasi-experimental study design along with qualitative interviews. Outcomes of interest are a) implementation, b) effectiveness related to processes and multi-agency collaboration, c) capacity building among professionals, d) child-related outcomes with a longitudinal follow-up as well as d) parental wellbeing and satisfaction.

Results: The model was launched in 2019 and so far, approximately 130 children have been assessed. Results from a pilot study with 62 children (27-72 months; boys: girls 2.65:1) show, using the strengths and difficulties questionnaire (SDQ), that the included children have clinically significant problems. The total mean SDQ score in parental rating was $15+/-6$ and in preschool teacher ratings $14+/-7$, exceeding the Swedish cut-off of 12.54 parents have participated in parental training and rate high levels of satisfaction (mean score 4.5, max 5.0). In addition, 74 pre-school professionals have been trained in early signs of neurodevelopmental difficulties to facilitate early detection. Feedback from these educational activities is encouraging (mean score 4.2, max 5.0).

Conclusions: The PLUSS-model enables early detection and interventions for preschool children and their families, without a set diagnosis. The pilot study shows that the screening procedure can detect children with clinically significant problems. In addition, encouraging results have been obtained from both parent- and preschool teacher training. The longitudinal study approach enables both child follow-up and evaluation of interventions provided by the working model.

Trial registration: Clinical Trials 2021, PLUSS identifier, NCT04815889. First registration 25/03/2021.

\section{Background}

Current research shows that it can be difficult to detect and diagnose neurodevelopmental symptoms and difficulties early in life. The earlier the difficulties are present, the higher the probability for several other symptoms [1, 2]. For preschool children, the prevalence of emotional and behavioural problems in international studies varies from 12-26\% [3-6]. These figures are often substantially higher than those based on diagnostic criteria according to DSM-IV, for example ADHD 2-8\%, 2-7\% [7-10]. Oppositional Defiant Disorder (ODD) 2-7\%, Conduct Disorder (CD) 1-3\%, Depressive Disorder 2-3\%, Separation Anxiety Disorder (SAD) $2.5 \%$ or Generalized Anxiety Disorder (GAD).

C Gillberg [1] has described the concept of ESSENCE (Early Symptomatic Syndromes Eliciting Neurodevelopmental Clinical Examinations) including various difficulties that become apparent during childhood such as language problems, motor skill deficiencies, increased activity level and impaired function of shared attention. In the Swedish population, the frequency of early (i.e., before school-start) identifiable ESSENCE difficulties is approximately $13 \%$ of all boys and $7 \%$ of girls. Around half of these children have been examined at a health care clinic by a doctor, speech therapist or psychologist before school start. Some of these, but not all, children subsequently meet the criteria for a specific diagnosis. 
There is often a great need for support in the close network to the affected child. Despite this, the current health care system rarely provides a multi-professional approach to these preschool children with various difficulties [1]. Even if a diagnosis may be clarifying, efforts to mitigate a child's day-to-day problems may be the most important for the families. Early developmental difficulties also entail an increased risk of impaired mental health, failure at school, crime, and social exclusion in adulthood [1]. These facts underline the importance of early intervention with optimal support for both strengths and difficulties $[11,12]$. Mental health is also strongly affected by demographics, ethnicity, and social factors, which is important to pay attention to in research and clinical work [13-15].

The PLUSS-model is based on Bronfenbrenner's bioecological model. According to this theory, a child's development is influenced by person-, process-, context- and time-dependent factors in various micro- (e.g., family, and preschool teachers) and macrosystems (e.g., preschool structure and policies) [16]. Also, a dynamic interplay between risk- and protective factors play a role in shaping the development over time [17]. Thus, a child 's behaviour shows age-related developmental changes $[18,19]$. For example, motor skills, language, self-esteem and emotional regulation are competencies that support a child's functional ability in everyday life [20-22].

The available research on child development, and the Swedish recommendations from the National Board of Health and Welfare, emphasize the importance of early identifying need for support and preventive actions. The Swedish Child health care $(\mathrm{CHC})$ work procedures are in line with the National Board of Health and Welfare's recommendations on early detection of developmental difficulties in children [23]. However, we see a need for further development to fully implement the guidelines and meet the needs of children and their parents [15].

In Sweden, follow up of a child's development is done at well-baby clinics by child health care nurses[24]. If needed, further assessment is done in specialized health care. There are specialized psychiatric teams/units for children below school-age (0-6 years) in some parts of Sweden and the other Nordic countries. These units collaborate with other multi-agency professionals like preschool teachers, who can identify difficulties and promote good mental health [25]. Interestingly, E Fält, A Sarkadi and H Fabian [26] reported that the quality of $\mathrm{CHC}$ routine visits for 3-5-year-olds improved when preschool teachers and parents actively participated as informants.

Several studies have shown that group-based support programs for parents can improve emotional and behavioural problems in preschool children [27]. Also, parental psychoeducation and counselling in communication skills and behavioural modification are important [28]. Early preventive interventions for preschool children have beneficial long-term effects and are financially motivated [12]. The most effective intervention seems to be parent- and pre-school interventions starting at an early age with focus on communication with the child [29-31].

\section{Methods}

\section{Aim}

To describe a novel multi-professional and multi-agency model, PLUSS (Mental health, learning, development, collaboration around pre-school children). 
The model is designed to match the needs of families and pre-school children with neurodevelopmental difficulties. This "one way in"-model provides coordinated services to screen, assess, and offer different interventions to the target group. In addition, we present initial data on the implementation and usage of the model.

\section{Design and settings of The PLUSS-model}

Since 2015, the CHC in Jönköping has developed its routines for early identification of communication and interaction difficulties (suspected autism spectrum disorders) in young children. The identified children were then first assessed by a CHP before referral to specialist level for in-depth assessment. The inflow of children from $\mathrm{CHC} / \mathrm{CHP}$ was greater than foreseen. As a result, $\mathrm{CHC}$ identified more children with these difficulties than before. The increase of inflow caused queues to build up for the Habilitation Center and raised questions on priority considerations towards other groups of children with disabilities. Although the children of the PLUSS target group have an important need of support and interventions as early as possible during their development - not all these children correspond to the group of patients managed by the Habilitation Center in the longer perspective (i.e., not all of them will be found to have an intellectual disability).

The $\mathrm{CHC}$ also recognized the need to clarify, and further collaborate with, the specialist level best suited to provide support and treatment for children younger than 6 years with complex attachment problems, trauma, and selective mutism. The Child and Adolescent Psychiatry (CAP) in Region Jönköping County has historically been meeting few children younger than 6 years. The age group is included in CAP's interface, but currently, there is no established team for pre-school age children at the CAP.

As the $\mathrm{CHC}$ developed its method of identifying children with neurodevelopmental difficulties early in life, the need for early interventions also increased. There was no arena for interventions for families and children under the age of six with neurodevelopmental or mental/psychological difficulties, without a requirement for a present diagnosis.

All above mentioned obstacles in the service system identified by The Jönköping Health Care Managers for CHC, Habilitation Center, Child and Adolescent Psychiatry (CAP) and Rehabilitation Center (Speech Therapist) formed the idea of a collaborative development team to coordinate and provide available interventions to a child's closest network; parents, preschool and, if necessary, involve the social services before the specialist level was reached. In 2018 multi-agency managers requested and obtained government funding for a collaborative project that was named PLUSS. In 2019, a steering group and an operative multi-professional and multi-agency working group were established. The local managers at preschools and social services were informed and invited to collaborate within the project.

Before PLUSS-project started, three semi-structured focus group interviews were completed, including 13 parents of children with behaviour and/or ESSENCE difficulties. Parents' experiences of assessment and interventions from Child Health Care, Child and Adolescent Psychiatry and Child and Youth Habilitation were studied. The analysis led to four main categories that should be considered in design of the working model: confidence, information, competence, and collaboration. Participants described a long wait for their child to be assessed and a lack of information that caused feelings of doubt. Furthermore, a lack of competence among health care professionals and a lack of cooperation with the family was described. Parents requested support to help their child whilst waiting for the assessment process. Increased competence for professionals was also asked for in 
areas of children's mental health and development. The need for improvements could be detected by taking part in parents' experiences with health care and health care professionals.

The model aims to accomplish a holistic perspective on children's daily life, preschool, family, and organizational aspects and to enable early intervention before any diagnosis. New initiatives are built upon already existing structures provided by the $\mathrm{CHC}$, family centers, preschools, social services and within the specialist level. Interventions in PLUSS are mostly provided in group forms, with groups matching the needs of the child and parents.

The PLUSS-model involves parents/appointed guardians, child health care, child and adolescent psychiatry, child and youth habilitation, rehabilitation center (speech therapists), preschools and social well-fare services as well as researchers from the Linköping University. The multi-professional competencies include pediatrics, child and adolescent psychiatry and habilitation, pre-school pedagogy and sociology.

A project leader heads the project and is assisted by an operative inter-professional working group consisting of local, experienced professionals. The group is created both for the continuous clinical work and for the development of the model. A steering group, involving representatives from different partners, gives advice, ensures delivery of the project outputs and the achievement of project outcomes. This management structure did not exist before the start of the project. The project leader is responsible for conveying information, if necessary, in between meetings. Meetings take place twice per semester. The professionals of the different departments and activities receive continuous information about the ongoing PLUSS-work.

The PLUSS-model is built upon existing processes for patient flow, from early detection to assessment and interventions (Fig. 1). No delay of routine practices such as primary assessment nor referral will be caused to patients in the PLUSS-flow. The waiting time for assessment by a CHP is approximately 6 months.

Information about PLUSS is given from a CHC-nurse to parents. Parents are then, before the visit to the CHP, asked to fill out questionnaires and sign a consent form for participation in PLUSS. Before the Corona pandemic, if participation was accepted, the forms were brought to the CHP's first assessment of the child. With digital assessment forms are sent in by post. During the first assessment, the CHP interviews the parents and obtains consent for contacting the preschool. The parents are then offered participation in parental training and educational activities (PRIMUS), see below. Data is then collected from the preschool and preschool teachers are offered a training program together with the parents.

The multidisciplinary PLUSS-team act as consultants to the child health care psychologist to assess the need for further examination within specialist care. This can be done after the completion of interventions or early in the process. After the PLUSS-team conference, parents are offered interventions recommended by the team. The menu of available interventions (Table 1) is a joint living document in which existing, and newly created initiatives, are gathered. The purpose of this list is to make all parties involved in the interventions available, through a clear and structured tool. The intervention list also clarifies the need for coordination between several actors and activities, such as between home and preschool. 
Table 1

Interventions provided by PLUSS

\begin{tabular}{|c|c|c|c|}
\hline Type of need & Type of intervention & Provider & $\begin{array}{l}\text { Receiver (C = } \\
\text { child, } P= \\
\text { parents, } G= \\
\text { group, } S= \\
\text { staff) }\end{array}$ \\
\hline $\begin{array}{l}\text { Regulation of emotions } \\
\text { and behaviour }\end{array}$ & -Parental support & $\mathrm{CHC}$ & $P$ \\
\hline $\begin{array}{l}\text { Problems in social } \\
\text { interaction and play with } \\
\text { peers }\end{array}$ & $\begin{array}{l}\text {-Special pedagogical support supervision } \\
\text { and efforts based on organization, group } \\
\text { and individual. }\end{array}$ & $\begin{array}{l}\text { CHC, } \\
\text { Preschool, } \\
\text { Habilitation }\end{array}$ & $\mathrm{C}, \mathrm{G}, \mathrm{S}$ \\
\hline $\begin{array}{l}\text { Problems in everyday } \\
\text { functioning. }\end{array}$ & -Function support - time aids etc. & $\begin{array}{l}\mathrm{CHC} \\
\text { Habilitation }\end{array}$ & $\mathrm{C}, \mathrm{P}, \mathrm{S}$ \\
\hline $\begin{array}{l}\text { Speech and language } \\
\text { related problems }\end{array}$ & $\begin{array}{l}\text {--Parental Education: Series Talks and } \\
\text { Social Stories } \\
\text {--The Swedish National Agency for } \\
\text { Education's reading lift, module several } \\
\text { languages in the preschool. } \\
\text {--Material that speech therapist/special } \\
\text { education teacher will share with preschool } \\
\text { staff who work with it from a group } \\
\text { perspective }\end{array}$ & $\begin{array}{l}\text { Habilitation, } \\
\text { Rehabilitation } \\
\text { Center } \\
\text { (speech } \\
\text { therapist) }\end{array}$ & $P$ \\
\hline Late motor development & -Physiotherapist assessment & Habilitation & C \\
\hline Anxiety & $\begin{array}{l}\text { - Parental support } \\
\text { - Support and treatment } \\
\text { - Preschool: special pedagogical supervision } \\
\text { and interventions based on organization, } \\
\text { group and individual. }\end{array}$ & $\mathrm{CHC}, \mathrm{CAP}$ & $P, S$ \\
\hline Early life adversity & $\begin{array}{l}\text { - Parental support } \\
\text { - Support and treatment } \\
\text { - TMO (trauma-conscious care) } \\
\text {-CPP }\end{array}$ & $\begin{array}{l}\text { CHC, CAP, pre- } \\
\text { schools, } \\
\text { social } \\
\text { services }\end{array}$ & $C, P, S$ \\
\hline Attachment problems & $\begin{array}{l}\text { - WWW } \\
\text { - Parental support } \\
\text { - COS-P } \\
\text { - Attachment trauma - differential diagnosis } \\
\text { autism } \\
\text { - COS-P as individual support } \\
\text { - Parental support/Family Treatment }\end{array}$ & $\begin{array}{l}\text { CHC, CAP, } \\
\text { social } \\
\text { services }\end{array}$ & $\mathrm{C}, \mathrm{P}, \mathrm{G}$ \\
\hline
\end{tabular}




\begin{tabular}{|c|c|c|c|}
\hline Type of need & Type of intervention & Provider & $\begin{array}{l}\text { Receiver ( } C= \\
\text { child, } P= \\
\text { parents, } G= \\
\text { group, } S= \\
\text { staff) }\end{array}$ \\
\hline \multirow{6}{*}{$\begin{array}{l}\text { Suspected or confirmed } \\
\text { disability of a child's } \\
\text { parent }\end{array}$} & Following aid decisions: & \multirow{6}{*}{$\begin{array}{l}\text { Social } \\
\text { services }\end{array}$} & \multirow[t]{6}{*}{$P$} \\
\hline & - Parental support/Family Treatment & & \\
\hline & $\begin{array}{l}\text { - Collaboration with other actors (disability } \\
\text { services etc) }\end{array}$ & & \\
\hline & - Network Meetings & & \\
\hline & - Contact family & & \\
\hline & $\begin{array}{l}\text { - Family home placement/network } \\
\text { placement }\end{array}$ & & \\
\hline \multirow{6}{*}{$\begin{array}{l}\text { Suspected or confirmed } \\
\text { mental illness in the } \\
\text { child's family or } \\
\text { immediate family }\end{array}$} & - Adult psychiatry & \multirow{6}{*}{$\begin{array}{l}\text { Social } \\
\text { services }\end{array}$} & \multirow[t]{6}{*}{$\mathrm{C}, \mathrm{P}$} \\
\hline & -Parental support/Family Treatment & & \\
\hline & - Collaboration with e.g. LSS or other actors & & \\
\hline & - Network Meetings & & \\
\hline & - Contact family & & \\
\hline & $\begin{array}{l}\text { - Family home placement/network } \\
\text { placement }\end{array}$ & & \\
\hline \multirow[t]{7}{*}{ Parental abuse } & - Parental support/Family Treatment & \multirow{7}{*}{$\begin{array}{l}\text { Social } \\
\text { services, CAP }\end{array}$} & \multirow[t]{7}{*}{$P$} \\
\hline & $\begin{array}{l}\text { - External outpatient care for children and/or } \\
\text { adults. }\end{array}$ & & \\
\hline & - Network Meetings & & \\
\hline & - Contact family & & \\
\hline & $\begin{array}{l}\text { - Family home placement/network } \\
\text { placement }\end{array}$ & & \\
\hline & $\begin{array}{l}\text { - Treatment via placement or outpatient care } \\
\text { for adult drug users }\end{array}$ & & \\
\hline & - CPP & & \\
\hline
\end{tabular}

The participants of the PLUSS-team are required to have a mandate to accept recommended referrals to their departments, to reduce the risk that some children "fall between chairs". The time required for each child included in PLUSS is estimated to be 5.5 hours, from the CHC nurse information to the PLUSS-team case discussion 


\section{Parental training PRIMUS}

The PRIMUS intervention comprises a total of five lessons, three hours each. It is a manual-based group program for parents with children between the ages of 3-6 years. The lessons are suitable for both small groups (8-12 participants) and large groups (15-30 participants). Lessons are held recurrently at the same time once a week. The topics that are covered in the program include child development, difficulties in concentration, motor skills, perception, tics and compulsions, difficulties in speech and language, social interaction, theoretical thinking as well as daily routines. This intervention aims to increase understanding of the child's difficulties; tools to help the child develop and increase functioning; more harmonious interaction between child and parents; reduced stress and frustration due to conflicts in the family and others around the child, as well as information to parents on where to turn for professional help.

\section{Preschool teacher training}

Apart from PRIMUS, an intervention for preschool teachers is offered, and Internet-based teacher training which parents also are encouraged to take part of. This intervention aims to facilitate cooperation between parents and preschool, to create a common ground for information sharing and reflection upon different perspectives, in the best interest of the child. The teacher training consists of seven film modules about normal development and common neurodevelopmental difficulties including self-regulation. In addition; communication, structure of everyday life and the role of clarifying methods in pedagogy are included. This is further deepened in a workshop, to which parents and preschool teachers are invited. During this workshop, the parents and preschool teachers jointly acquire practical approaches in areas included in the education/training; clarifying methods in pedagogy, communication, and support in everyday life. With the child in mind, the parents and preschool teachers discuss and try different relevant exercises. The participants collect their thoughts in an "action list" in which common strategies and approaches are planned to stimulate the child's development both at home and in the educational environment.

\section{Other interventions}

The available interventions can be individual assessments and/or interventions for the child, family, and preschool (Table 1). These can be offered by a special educator, speech therapist or occupational therapist; targeted parent groups in the form of "Emotional children"; targeted parent groups in the form of "toilet school"; support in basic interaction; parental support and treatment; recommendations regarding the social services' general and targeted efforts - in consultation with the social secretary on-site; recommendations regarding the preschool's general and targeted efforts - in consultation with the special educator's competence in the area.

\section{Study population of the pilot study}

The PLUSS-model targets children who are referred to a CHP due to problems related to neurodevelopment. These difficulties are most often detected at a routine visit to the $\mathrm{CHC}$ when the child is 2.5 years old. During this routine visit, a nurse assesses development and screens for developmental difficulties. The most common causes for a psychologist consultation (and criteria for inclusion the PLUSS-model) are developmental delay, impairment in social interaction or motor skills, language and communication difficulties, hyperactivity, difficulties with concentration, self-regulation and behavioural problems, fear, anxiety, or other difficulties in everyday life. Feedback from the child's preschool is collected as a part of routine visits to CHC. No exclusion 
criteria are applied, except for parents only requesting support in their parental role. Furthermore, there is no eligibility requirement regarding a set diagnosis.

The model is currently employed in three out of 13 municipalities in Jönköping County and involves 18 professionals. The child population (0-18 years) is 76394 in the whole of Jönköping County with 18060 children between ages 1.5-5 years. Based on local statistics approximately 1806 children (10\%) per year are expected to require assessment for neurodevelopmental difficulties in Jönköping County. Approximately $24 \%$ are born abroad or to immigrant parents, compared to a national number of $25 \% .95 \%$ of children in the target group participate in preschool activities. Close to $100 \%$ of children aged between $0-5$ years attend the $\mathrm{CHC}$ routine checkups in Region Jönköping County. These routine check-ups are offered free of charge.

By now, approximately 130 children between ages 27-72 months have been assessed through the PLUSS approach. In the three municipalities employing the model so far, the child population within target ages is 8858 . In 2020, 63 referrals for children aged 1-5 years were made to the CAP of Region Jönköping County. During the same year, 158 referrals were made to the Habilitation Center, out of which 127 came from $\mathrm{CHC}$. At the Habilitation Center, many 1-5 years old children wait 12-18 months for further assessment and interventions. The CAP, who in comparison receive fewer referrals for children aged 1-5 years, choose to prioritize this age group to minimize waiting time, which other age groups within CAP have.

\section{Data collection}

The PLUSS-project is studied within a research project that was retrospectively registered in Clinical Trials 2021, PLUSS identifier, NCT04815889. Child data is collected using the following instruments: Strength and Difficulties Questionnaire (SDQ) [32,33] rated by preschool teachers and parents, Child Engagement Questionnaire (CEQ) [34] rated by preschool teachers, LAPS [35] rated by child health care psychologists at baseline and CHC nurses at follow-up and JA-OBS [36] rated by $\mathrm{CHC}$ nurses. Data will be collected at baseline, after any PLUSS intervention and at the regular 5-year old visit to the $\mathrm{CHC}$.

Parent data will be collected through a separate questionnaire that covers different background factors such as profession, educational level, mother tongue or any earlier or present diagnoses. In addition, data on parental stress, satisfaction of interventions etc. will be collected. Qualitative data will be collected through focus group interviews with parents of children participating in PLUSS.

Structured follow-up research on collaboration between different PLUSS activities will be collected with a method called the Spider [37]. This is done before the PLUSS-model and then again every 6 months with professionals in the organization working with children/families in the target group.

Register data will be used for waiting time follow-up, number of visits and involved professionals, offered and completed interventions as well as other process-related outcomes. Data collection is managed by researchers and people in the operative working group with a special assignment for follow-up and organization of submitted forms. Data is obtained from parents, preschool teachers, $\mathrm{CHC}$ nurses and CHC psychologists.

A control group $(n=160)$ is recruited from municipalities that have not yet been included in the PLUSS clinical trial. Through this, children/families are not withheld from treatment that they would otherwise have received.

\section{Data analysis}


Data is analyzed using quantitative analyses in SPSS. Demographic data is presented in numbers and percentages. Mean values are analyzed concerning cut-off for SDQ full-scale sum and subscales. Spearman correlation analyses are done between LAPS full-scale sum, SDQ full-scale sum and between CEQ average and SDQ full-scale sum. The parents' focus group interviews and the ongoing preschool teacher interview study are analyzed qualitatively with content analysis.

\section{Results}

A pilot study was conducted in the PLUSS-project; 62 children (45 boys and 17 girls) aged 27 months - 72 months were included. The mean age was 4.6 years (54 months) with a standard deviation of 12 months. $75.4 \%$ of the children had Swedish as their mother tongue and $24.6 \%$ had another mother tongue. For demographic data (see Table 2) regarding parents' highest level of education: 6.8\% have completed Swedish compulsory school of 9 years, $30.5 \%$ upper secondary school, $54.2 \%$ higher education $54.2 \%$ and $8.5 \%$ other education. Regarding employment, $1.8 \%$ of the parents were unemployed, $87.3 \%$ were employed and $10.9 \%$ had other employment (on sick leave). These results correspond well to the country of Sweden as a whole.

Table 2

Demographic data including gender, age, mother tongue and information about parents' education and employment.

\begin{tabular}{|lll|}
\hline & Number & Percent \\
\hline Girls & 17 & 27.5 \\
\hline Boys & 45 & 72.5 \\
\hline Mean Age (month) & 54 & \\
\hline Children's Mother Tongue & & \\
\hline Swedish & 46 & 75.4 \\
\hline Other & 15 & 24.6 \\
\hline Parents' education level & & \\
\hline Compulsory school (9 years) & 4 & 6.8 \\
\hline Upper secondary school & 18 & 30.5 \\
\hline Higher education & 32 & 54.2 \\
\hline Other education & 5 & 8.5 \\
\hline Parents' employment & & \\
\hline Unemployed & 1 & 1.8 \\
\hline Employed & 68.3 & \\
\hline Other employment (sick leave) & 6 & \\
\hline
\end{tabular}

\section{Neurodevelopmental problems}


In the pilot study, the SDQ-estimates from both parents (15.5) and preschool teachers (14.5) captured children in need of support based on the Swedish cut-off value of 12 points for the SDQ full scale and supplements that measure everyday functioning (cut-off 1 point) [2]. The reported scores were above the cut-off for the subscales Hyperactivity and Prosocial Behavior, for both parents and preschool teachers as informants. For the subscales Peer Problems and Emotional Problems, both parents' and preschool teachers' scores were below the cut-off. Furthermore, parents' scores were borderline lower than cut-off values for the subscale Behavioral problems. See Table 3.

Table 3

Mean values and cut-off values for SDQ subscales filled out by guardians and preschool teachers. The Mann Whitney U-test (two-tailed) was used for comparisons between boys and girls.

\begin{tabular}{|c|c|c|c|c|c|}
\hline & $\begin{array}{l}\text { Swedish cut- } \\
\text { off }\end{array}$ & $\begin{array}{l}\text { Parent } \\
\text { rating }\end{array}$ & $\begin{array}{l}\text { Group } \\
\text { comparison }\end{array}$ & $\begin{array}{l}\text { Preschool } \\
\text { rating }\end{array}$ & $\begin{array}{l}\text { Group } \\
\text { comparison }\end{array}$ \\
\hline & & mean (SD) & $\mathrm{p}$ & $\begin{array}{l}\text { mean } \\
(S D)\end{array}$ & $\mathrm{p}$ \\
\hline Total score & 12 & $15(6)$ & .058 & $14(7)$ & \\
\hline $\begin{array}{l}\text { Behavioural } \\
\text { Problems }\end{array}$ & 4 & $4(2)$ & & $3(2)$ & \\
\hline Hyperactivity & & $6(3)$ & .046 & $6(3)$ & \\
\hline Peer problems & 4 & $3(2)$ & .034 & $3(2.5)$ & .009 \\
\hline Emotional problems & 3 & $3(2)$ & & $2(2)$ & \\
\hline Prosocial behaviour & 3 & $6(2)$ & .014 & $5(3)$ & \\
\hline $\begin{array}{l}\text { Supplement } \\
\text { function }\end{array}$ & 1 & $6(4)$ & .050 & $5.5(3.5)$ & \\
\hline
\end{tabular}

Boys were by preschool teachers rated to have more difficulties $(p .=.058$, mean $15+/-6)$ than girls (mean $11+/-$ 8) on the total SDQ scale and on the subscales hyperactivity ( $\mathrm{p} .046$, mean 6.5 +/- 3) (girls; mean $5+/-3$ ), and peer problems ( $\mathrm{p} .034$, mean $3+/-2$ ) (girls; mean $2+/-2.5$ ). Boys were also rated to have significantly more problems in everyday functioning ( $p$.050) using the SDQ Supplement (mean $6+/-3.5$ ) than girls (mean $4+/$ $3.5)$. Boys were also rated to have significantly ( $p$.014) less pro-social skills (mean $4+/-3$ ) than girls (mean $7+/-$ 3 ). When parents estimated SDQ, the only significant difference was more peer problems in boys ( $p$.009, mean 3 $+/-2$ ) than girls (mean $2+/-2$ ).

When assessing both median and mean values for SDQ subscales, supplements and full-scale sums, there was no statistically significant difference between how parents and preschool teachers reported the same child, except for the subscale Prosocial Behavior where parents reported higher average values. The pilot study showed that both parents' and preschool teachers' estimates are relevant for capturing early symptoms of mental illness in preschool children and that the children included in PLUSS need support.

Spearman correlation analyses showed a positive relationship between LAPS full-scale sum (filled out by CHC psychologists) and SDQ full-scale filled out by parents (0.36 rho Spearman, sig 0.01). No correlation was seen between LAPS and SDQ full-scale filled out by preschool teachers. Thus, parents and CHC psychologists tended 
to evaluate the child similarly. CEQ average score for the children in PLUSS was 2.77 and for the Swedish normal population average score was 3.21 (BM Gustafsson [11]. There was a negative correlation between CEQ average and SDQ full scale filled out by preschool teachers (-0.50 rho Spearman, sig 0.01). Thus children who were seen by preschool teachers as engaged (high values of CEQ), were also estimated to have lower scores in SDQ.

\section{Parental training}

Parents ( $n=97$, divided into 8 groups) of 64 children participated in parental training groups with high levels of satisfaction (satisfaction mean score 4.5 , max 5.0). Both parents participated in the group with a proportion of $54 \%$, the only mother $38 \%$, only father $8 \%$ and appointed guardians $2 \%$.

\section{Preschool teacher training}

Preschool teachers, special educators, and directors of preschools ( $n=86$, divided into 8 groups) of 54 children were trained in early signs of neurodevelopmental difficulties to facilitate early detection. Feedback from these educational activities is encouraging (satisfaction mean score 4.2, max 5.0).

\section{Discussion}

The PLUSS-model has been launched and successfully implemented in the County of Jönköping. Professionals have easily been recruited to the project and have contributed to the development of the processes/interventions included in PLUSS - both within the Region and the municipality's activities.

Based on Bronfenbrenner's theory [16] PLUSS holds an advantage in including social services in the model allowing the child's entire context to be supported based on the needs of the child. The preschool can also be supported by the interventions supplied by the PLUSS-model regarding the child's everyday functioning [38]. The results from the focus groups show that the PLUSS-model bridges a gap for parents of children in the target group: early interventions and increased knowledge on neurodevelopmental difficulties was called for, both in health care professionals as well as within preschools. The results from the parents' and preschool teachers' estimates, show high scores of behavioural problems in SDQ and low engagement in CEQ, implying that the target group of PLUSS are children in need of early detection and interventions.

Results from both parents' and preschool teachers' evaluations of the training program in PLUSS (PRIMUS) show high satisfaction mean scores (4.5 out of 5) from parents and encouraging mean scores from preschool teachers (4.2 out of 5). PRIMUS provides an arena for parents to meet and share experiences of children with neurodevelopmental difficulties, and an arena for the preschool and parents to meet and discuss the strengths and difficulties of the child in focus.

Results from previous studies with a similar approach have shown that the most effective intervention seems to be parent and preschool interventions starting at an early age, with a focus on communication [29, 31, 39]. Several studies have shown that group-based support programs for parents can improve emotional and behavioural problems in preschool children [27]. Unlike earlier studies, such interventions will be possible to evaluate long-term within the PLUSS-model.

Fewer referrals than expected have been received by the PLUSS-team. From January- April 2021, 10 children were referred to the team. One possible factor for causing delay of referrals is the consent from parents which is 
obtained on paper, while the CHP assessment interview is held online due to the Corona pandemic, causing a risk for the consent form to be forgotten or delayed. The health care data system in the Region currently neither provides a solution for questionnaires nor for consent forms to be sent in digitally.

The CHP might also find it less time consuming to refer a child directly to specialist care, than to the PLUSSteam, with the concept of further discussing the patient with the team. Although with the intent of an atmosphere of openness, there is a risk for the CHP to feel questioned or criticized during the case presentation, thus increasing the risk for refraining from referral. There might also be a risk that information and understanding of the PLUSS-model may not be the same within the whole CHP-group - leading to fewer referrals to the PLUSSteam. Continuous information about the PLUSS-model is sent to the child health psychologists in the Region.

Cooperation between the region and municipality has increased through the PLUSS-model. From this, the understanding of the respective activities is expected to increase, leading to beneficial development, and further bridging of identified gaps in the care for preschool children with developmental difficulties. The PLUSS-model enables evidence-based methods for behavioural problems, such as the Incredible Years parent program [40] to be included in research work after implementation in a unit such as the CAP in Jönköping.

An important aim

for future research in the PLUSS-model is to follow the included children long-term regarding symptom development, set diagnoses and evaluate given interventions. Parental stress and perceived competence in parents to children with neurodevelopmental difficulties is also important to study.

To improve the mental health of children in Sweden, a suggestion of five evidence-based interventions was recently published, one of them being early detection and early interventions for young people with risk for future mental health problems [41]. Current knowledge indicates that early detection and early interventions for children are beneficial long term and economically justifiable [12, 42]. The PLUSS-model has been constructed to better meet the demands of health care today with early interventions to parents and children exhibiting neurodevelopmental difficulties.

\section{Conclusions}

The PLUSS-model includes early screening and early detection of neurodevelopmental difficulties in preschool children, and group interventions are offered before any set diagnoses. The model requires collaboration between health care and municipal activities. Through the PLUSS screening procedure with SDQ-questionnaires, children in need of support can be detected. The preliminary results show that both parents and preschool teachers' estimates are relevant for capturing early symptoms of mental illness in preschool children. Encouraging results are seen in parent and preschool evaluations of given interventions.

\section{Abbreviations}

ADHD, attention deficit hyperactivity disorder

CAP, child and adolescent psychiatry

CEQ, child engagement questionnaire 
CD, conduct disorder

$\mathrm{CHC}$, child health care center

$\mathrm{CHP}$, child health care psychologist

ODD, oppositional defiant disorder

$\mathrm{GAD}$, generalized anxiety disorder

JA-OBS, joint attention observation tool

LAPS, lapsen psykososiaalisen terveyden arviointimenetelmä (child mental health assessment form)

PLUSS, Psykisk hälsa Lärande Utveckling Samverkan kring Små barn (mental health, learning, development, collaboration around pre-school children)

SAD, separation anxiety disorder

SDQ, strengths and difficulties questionnaire

\section{Declarations}

\section{Ethics approval and consent to participate}

All research included in the PLUSS-model has been approved by the National Ethics Review Board, \#201904839. Informed consent is obtained from all study participants and legal guardians if the participant is younger than 15 years.

\section{Consent for publication}

Not applicable

\section{Availability of data and materials}

The datasets used and/or analyzed during the current study are available from the corresponding author on reasonable request.

\section{Competing interests}

The authors declare that the research was conducted in the absence of any commercial or financial relationships that could be construed as a potential conflict of interest.

\section{Funding}


This study is funded by governmental "Tillsammanspengar" granted for the County of Jönköping. This work was also supported by FUTURUM grant number 910161 and 910441 . The funders had no role in designing the study, writing the report or in the decision to submit the paper for publication.

\section{Authors' contributions}

BG and LK conceived the idea for the study, designed the study and drafted the manuscript. BG analyzed the data and prepared figure and tables. SS analyzed the data and provided feedback on drafts. All authors approved the final submitted version.

\section{Acknowledgements}

The authors want to thank all involved partners and families that have participated in the project.

\section{Authors' information}

Berit Gustafsson, PhD RN, works as a research leader at the Psychiatric Clinic at Högland Hospital in Jönköping County.

Samina Steinwall, MD, is PhD student at Linköping University and is a resident at the Department of Child and Adolescent Psychiatry in Region Jönköping County.

Laura Korhonen, MD PhD, is professor of child and adolescent psychiatry at Linköping University and head of Barnafrid, Swedish National Center on Violence Against Children.

\section{References}

1. Gillberg C: The ESSENCE in child psychiatry: Early Symptomatic Syndromes Eliciting Neurodevelopmental Clinical Examinations. Res Dev Disabil 2010, 31(6):1543-1551.

2. Gustafsson BM, Proczkowska-Björklund M, Gustafsson PA: Emotional and behavioural problems in Swedish preschool children rated by preschool teachers with the Strengths and Difficulties Questionnaire (SDQ). BMC pediatrics 2017, 17(1):110.

3. Costello EJ, Egger H, Angold A: 10-year research update review: the epidemiology of child and adolescent psychiatric disorders: I. Methods and public health burden. J Am Acad Child Adolesc Psychiatry 2005, 44(10):972-986.

4. Furniss T, Beyer T, Guggenmos J: Prevalence of behavioural and emotional problems among six-years-old preschool children. Soc Psychiatry Psychiatr Epidemiol 2006, 41(5):394-399.

5. Keenan K, Shaw DS, Walsh B, Delliquadri E, Giovannelli J: DSM-III-R disorders in preschool children from low-income families. Journal of the American Academy of Child and Adolescent Psychiatry 1997, 36(5):620-627.

6. Lavigne JV, Binns HJ, Christoffel KK, Rosenbaum D, Arend R, Smith K, Hayford JR, MCGuire PA: Behavioral and emotional problems among preschool children in pediatric primary care: prevalence and pediatricians' 
recognition. Pediatrics 1993, 91(3):649-655.

7. Egger HL, Kondo D, Angold A: The Epidemiology and Diagnostic Issues in Preschool AttentionDeficit/Hyperactivity Disorder: A Review. Infants \& Young Children 2006, 19(2):109-122.

8. Gadow KD, Sprafkin J, Nolan EE: DSM-IV symptoms in community and clinic preschool children. Journal of the American Academy of Child \& Adolescent Psychiatry 2001, 40(12):1383-1392.

9. Thomas R, Sanders S, Doust J, Beller E, Glasziou P: Prevalence of attention-deficit/hyperactivity disorder: a systematic review and meta-analysis. Pediatrics 2015, 135(4):994-1001.

10. Wichstrøm L, Berg-Nielsen TS, Angold A, Egger HL, Solheim E, Sveen TH: Prevalence of psychiatric disorders in preschoolers. Journal of child psychology and psychiatry, and allied disciplines 2012, 53(6):695-705.

11. Gustafsson BM: Identifying Patterns of Emotional and Behavioural Problems in Preschool children: Facilitating Early Detection. Med. Linköping: Linköping University Electronic Press, 2018., s. 126: Linköping University; 2019.

12. Heckman JJ: Skill formation and the economics of investing in disadvantaged children. Science 2006, 312(5782):1900-1902.

13. Utvecklingsområden för mödra- och barnhälsovård samt elevhälsa [https://www.google.com/url? $s a=t \& r c t=j \& q=\& e s r c=s \&$ source=web\&cd=1\&cad=rja\&uact=8\&ved=2ahUKEwj-

r_P78fbcAhURqaQKHY8FBxEQFjAAegQIARAC\&url=https\%3A\%2F\%2Fkfsk.se\%2Flarandeocharbetsliv\%2Fwpcontent\%2Fuploads\%2Fsites\%2F8\%2F2014\%2F12\%2FUtvecklingsomraden-for-modra-och-barnhalsovardsamt-elevhalsa-\%25E2\%2580\%2593-en-kartlaggning-av-professionernas-onskemal-om-riktlinjer-eller-annanvagledning.pdf\&usg=AOvVaw3Kf4DMNoEMxzOTLoLnPmZY]

14. Discovering Mental Illness [http://www.socialstyrelsen.se/publikationer2013/2013-1-8]

15. Petersen S, Bergström E, Cederblad M, Ivarsson A, Köhler L, Rydell A, Stenbeck M, Sundelin C, Hägglöf B: Barns och ungdomars psykiska hälsa i Sverige. En systematisk litteraturöversikt med tonvikt på förändringar över tid Stockholm: Kungl Vetenskapsakademien, Hälsoutskottet 2010.

16. Bronfenbrenner U, Morris PA: The ecology of developmental processes. 1998.

17. Wille N, Bettge S, Wittchen HU, Ravens-Sieberer U: How impaired are children and adolescents by mental health problems? Results of the BELLA study. European child \& adolescent psychiatry 2008, 17 Suppl 1:4251.

18. Hensch TK: Critical period regulation. Annu Rev Neurosci 2004, 27:549-579.

19. Erikson EH: Toys and reasons: Stages in the ritualization of experience. New York: WW Norton \& Company; 1977.

20. Hebbeler K, Rooney R: Accountability for services for young children with disabilities and the assessment of meaningful outcomes: The role of the speech-language pathologist. Language, Speech, and Hearing Services in Schools 2009, 40(4):446-456.

21. Kjellmer L, Hedvall Å, Fernell E, Gillberg C, Norrelgen F: Language and communication skills in preschool children with autism spectrum disorders: Contribution of cognition, severity of autism symptoms, and adaptive functioning to the variability. Research in developmental disabilities 2012, 33(1):172-180.

22. Phillips DA, Shonkoff JP: From neurons to neighborhoods: The science of early childhood development. Washington, D.C: National Academies Press; 2000. 
23. National Board of Health and Welfare: Guidance for Child Health Care (Vägledning för barnhälsovården). In., vol. $2021 ; 2014$.

24. Björn Wettergren MB, Anders Hjern, Olle Söder, Jonas F Ludvigsson Child Health Systems in Sweden. J Pediatr2016, Oct;177S:S:187-202.

25. Almqvist L, Hellnäs P, Stefansson M, Granlund M: 'I can play!'Young children's perceptions of health. Pediatr Rehabil 2006, 9(3):275-284.

26. Fält E, Sarkadi A, Fabian H: Exploring Nurses', Preschool Teachers' and Parents' Perspectives on Information Sharing Using SDQ in a Swedish Setting-A Qualitative Study Using Grounded Theory. PLoS One 2017, 12(1):e0168388.

27. Barlow J, Bergman H, Kornør H, Wei Y, Bennett C: Group-based parent training programmes for improving emotional and behavioural adjustment in young children. Cochrane Database of Systematic Reviews 2016(8).

28. Ferm U, Andersson, M., Broberg, M., Liljegren, T., \& Thunberg, G.: Parents and course leaders' experiences of the ComAlong augmentative and alternative communication early intervention course. Disability Studies Quarterly, 2011, 31(4).

29. Devescovi R, Monasta L, Mancini A, Bin M, Vellante, Carrozzi M, Colombi C: Early diagnosis and Early Start Denver Model intervention in autism spectrum disorders delivered in an Italian Public Health System service. Neuropsychiatr Dis Treat 2016, 12:1379-1384.

30. Jones D, Godwin J, Dodge KA, Bierman KL, Coie JD, Greenberg MT, Lochman JE, McMahon RJ, Pinderhughes EE: Impact of the Fast Track prevention program on health services use by conduct-problem youth. Pediatrics 2010, 125(1):e130-e136.

31. Spjut Jansson B, Miniscalco C, Westerlund J, Kantzer A-K, Fernell E, Gillberg C: Children who screen positive for autism at 2.5 years and receive early intervention: a prospective naturalistic 2-year outcome study. Neuropsychiatr Dis Treat 2016, 12:2255.

32. Gustafsson BM, Gustafsson PA, Proczkowska-Bjorklund M: The Strengths and Difficulties Questionnaire (SDQ) for preschool children-a Swedish validation. Nordic journal of psychiatry 2016:1-8.

33. SDQ Information [http://www.sdqinfo.org]

34. McWilliam R: Children's engagement questionnaire. Chapel Hill, NC: Frank Porter Graham Child Development Center, University of North Carolina 1991.

35. Borg A-M, Kaukonen, P., Salmelin, R., Miettinen, S., Mäntymaa, M., Joukamaa, M., \& Kaija Puura, T.: Mental health assessment form for 4- to 13-year-old children. Finnish Medical Journal Duodecim 2019, 135:393402.

36. Nygren G, Sandberg E, Gillstedt F, Ekeroth G, Arvidsson T, Gillberg C: A new screening programme for autism in a general population of Swedish toddlers. Research in developmental disabilities 2012, 33(4):1200-1210.

37. Danermark B, Germundsson P: Att studera samverkan i ett interaktionistiskt perspektiv. Collaboration "Spider" measurment. In., edn. Lund: Studentlitteratur AB, 2013. s. 329-343; 2013.

38. Andersson AK, Martin L, Brodd KS, Almqvist L: Predictors for everyday functioning in preschool children born preterm and at term. Early Human Development 2016, 103:147-153.

39. Franke N, Keown LJ, Sanders MR: An RCT of an online parenting program for parents of preschool-aged children with ADHD symptoms. Journal of attention disorders 2020, 24(12):1716-1726.

Page $17 / 19$ 
40. Webster-Stratton C, Sandberg, A., Mostyn, D: De otroliga åren: en handledning i problemlösning för föräldrar till barn mellan tre och åtta år.. Lund: Palmkron; 2004.

41. Kraftsamling för ungas psykiska hälsa [https://www.sls.se/globalassets/sls/dokument/rapportkraftsamling-for-ungas-psykiska-halsa-20210521.pdf]

42. Dodge KA, Bierman KL, Coie JD, Greenberg MT, Lochman JE, McMahon RJ, Pinderhughes EE, Group CPPR: Impact of early intervention on psychopathology, crime, and well-being at age 25. Am J Psychiatry 2014, 172(1):59-70.

\section{Figures}

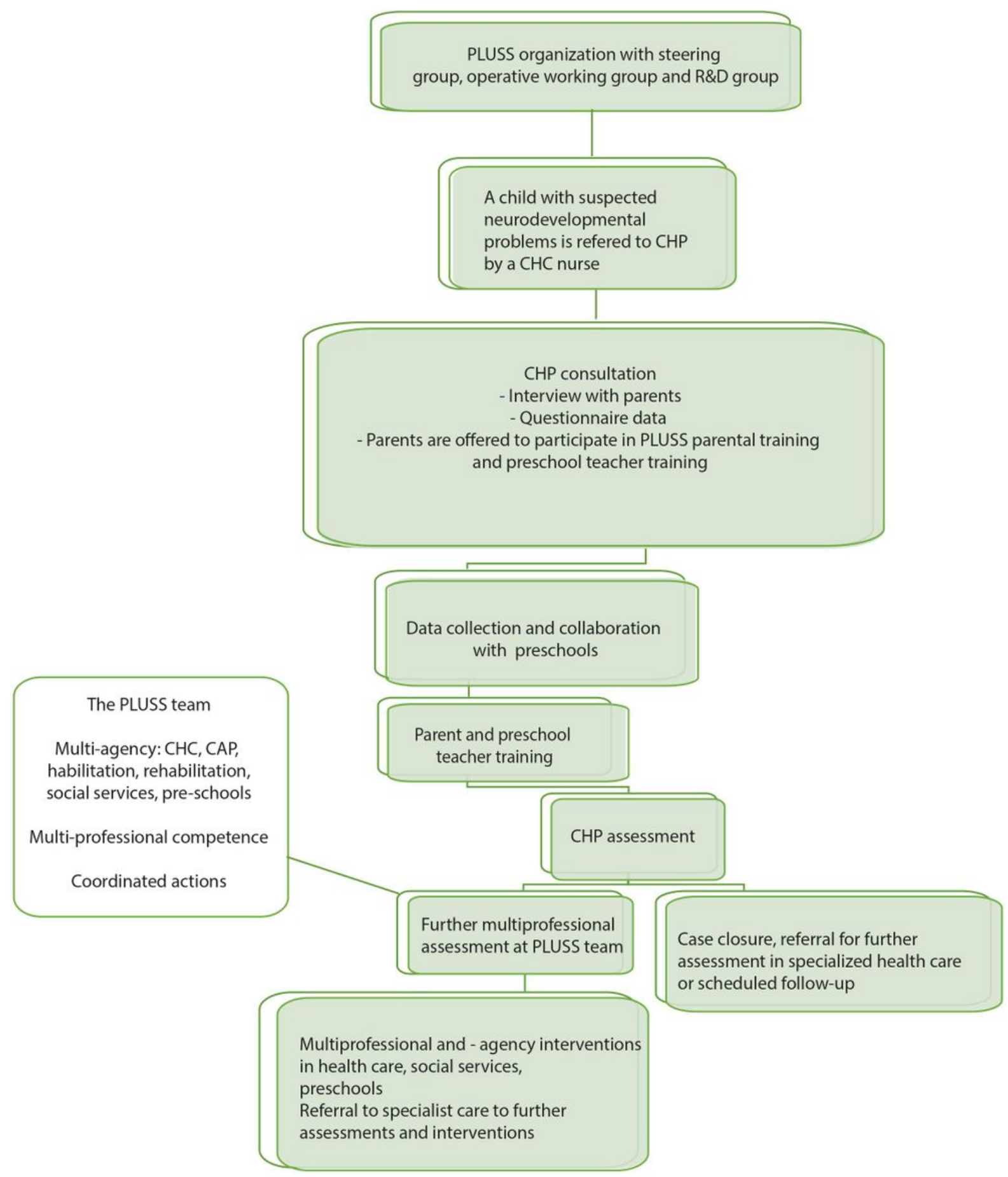




\section{Figure 1}

The PLUSS-model is built upon existing processes for patient flow, from early detection to assessment and interventions (Figure 1). 